\title{
THE INFLUENCE OF CHRONIC LEAD POISONING ON THE ACTIVITY OF SOME SERUM
} ENZYMES IN RATS

\author{
TODOROVIĆ TATJANA*, DOŽIĆ I*, VUJANOVIĆ DRAGANA**, PEJOVIĆ J*** \\ and MARJANOVIĆ $\mathrm{M}^{\star * *}$ \\ *Faculty of Stomatology, Belgrade; **Faculty of Pharmacy, Belgrade; \\ $\star * \star$ Military Medical Academy, Belgrade \\ (Received 4. April 2005)
}

In this paper, the influence of chronic lead intoxication on the activity of serum enzymes aspartate and alanine aminotransferases (AST and $A L T)$ and alkaline phosphatase $(A L P)$ was examined.

The experiment was performed on 130 adult female DA rats and 80 young rats. Rats were treated by lead-acetate 100 and $30 \mathrm{mg} P b$ per $\mathrm{kg}$ body weight for 10, 20, 30, 40, 50 and 60 days. Young rats (offspring of studied female rats) were treated with lead only through the placenta and mother's milk. The activities of serum AST, ALT and ALP were determined spectrophotomerically by IFCC method.

The activity of examined serum enzymes was significantly increased in conditions of chronic lead intoxication in female rats and their offspring in relation to the control group. The activity of serum AST, $A L T$ and ALP was in a positive correlation with the time of intoxication. There were no significant differences between the activities of enzymes AST and ALT in the serum and the amount of lead. The activity of ALP was significantly higher in serum of rats treated with higher amounts of lead.

Increased AST, ALT and ALP activity in serum is most likely the consequence of lead hepatotoxicity.

Key words: lead, hepatotoxicity, enzymes, AST, ALT, ALP

\section{INTRODUCTION}

All living organisms are made of organic substances and numerous chemical elements. There are 92 elements in nature, and 81 of them are found in human and animal organisms. Out of these, 22 elements are considered as essential for the organism, such as Fe, J, Cu, Zn, Mn, Co, Cr, Mo, F, Se, Li, H, C, N, $\mathrm{O}, \mathrm{P}, \mathrm{S}, \mathrm{Na}, \mathrm{K}, \mathrm{Mg}, \mathrm{Ca}, \mathrm{Cl}$. Ni, V. As and Si are found to be necessary for animal organisms only. There are also elements which are permanently present in organisms in various concentrations and it is believed that their presence comes as a result of contamination, i.e. from contacts with the environment (Al, $\mathrm{Hg}, \mathrm{Cd}$, $\mathrm{Pb}, \mathrm{Bi}, \mathrm{Ag}$ ) (Majkic-Singh, 1993). 
Among toxic elements, lead has a leading role and lately it has drawn great attention due to the increasing contamination of the environment. Lead entering the human organism (most often by inhalation and ingestion) is deposited mostly in the liver and particularly in calcified tissues (bones and teeth). Due to this property, lead takes the first place on the list of the so-called osteotrophic or "bone seeking" elements (Aungust and Fung, 1985; Bogdanović, 1991; Bronner, 1991; Aufderheide,1993; Davis, 1993; Gerhardsson, 1996; Hac and Krechinak, 1996) This element has toxic effects to almost all organs and especially sensitive are: the nerve system, hematopoetic system, kidneys, liver and hard tissues (Long, 1990; Pounds, 1991; Kahng, 1992; Patersson and Settle, 1993; Miyuhara, 1994; O Flaherty, 1995).

Toxicity of lead is expressed inter alia by changes in the activities of certain enzymes. Namely, lead can directly destroy the enzyme structure by inter-reacting with bioelements built in the metalloenzymes as in the case of $\Delta$-aminolevulinic acid dehydratase (ALAD) which enables the process of HEM biosynthesis and subsequently results in theoccurrence of anemia (Ischiba and Tomokulin, 1988; Angle, 1993; Atef, 1994; Ambrogi, 1996). In addition to this, when exposed to increased lead concentrations, the activities of certain enzymes can be disturbed as a direct consequence of damages to the tissues and organ cells (Nilsson, 1991; Atef M, 1994; Nehru and Kausahal, 1993; Miyuhara, 1994; Singh, 1994; Sollivaj, 1996; Selander, 1996).

This study investigates the effects of chronic lead poisoning on the activities of alanine and aspartate aminotransferases (ALT and AST) and alkaline phosphatase (ALP) in the blood sera of female rats and their offspring.

The aim of this study was to analyze the activities of the AST, ALT and ALP enzymes in the blood sera of rats in conditions of chronic lead poisoning. The above aim was fulfilled by defining the activities of the above enzymes in the blood sera of female rats and their offspring in conditions of chronic lead intoxication and in relation to the control group, the period of intoxication and lead dose.

\section{MATERIALS AND METHODS}

A biological experiment was conducted at the Institute for Experimental Researche of the Military-Medical Academy. Research included:

- 130 female rats of the DA strain, weighing about $200 \mathrm{gr}$, and 5-6 months of age,

- 80 young offspring of the above females, 2 months old and about $100 \mathrm{gr}$ of weight.

The premises where the experimental animals were situated were kept under strict control in view of lighting, temperature, air humidity and cleanness. The animals were fed on basic, standard, pelleted food in accordance with the regulations governing the feeding of laboratory animals.

Lead in the form of lead - acetate $\left(\mathrm{Pb}\left(\mathrm{CH}_{3} \mathrm{COO}\right)_{2}\right)$ was given to female rats orally, by means of water. Each female was put in a separate cage and the quantity of taken water was measured every day on the basis of changes in the flask's weight. In this way, the lead-acetate concentration taken in with water by each 
female was controlled every day. Lead acetate was selected among other lead salts due to its better solubility and hence its better level of absorption in the digestive tract compared to other salt types (Dieter, 1993; Freeman, 1994) Concerning the choice of the way in which lead is administered we decided on oral application because of the simplicity of this procedure and because it is, in addition to inhalation, the most common natural way of getting into the human organism i.e. by contaminated water and food intake.

Lead - acetate was administered to experimental animals in either smaller or larger doses, i.e. in $100 \mathrm{mg} / \mathrm{kg}$ body mass (BM) daily or $30 \mathrm{mg} / \mathrm{kg} \mathrm{BM}$ daily within periods of 10, 20,39, 40, 59 and 60 days. These quantities of lead - acetate are considered as subtoxic doses and, no matter they were increased, they did not cause lethal or toxic effects to the rats. Namely, these doses of lead were determined on the basis of data relating to lethal and toxic effects of certain lead salts (Bogdanovic, 1991; Freeman, 1994).

The duration of the entire experiment was 60 days, i.e. the females were tested with lead - acetate 10 days before mating, 7 days during mating, 21 days during pregnancy and 21 days during the period of lactation. However, not all females passed all the indicated phases because each 10 days a group of 20 females was sacrificed (10 females from the group receiving the lead-acetate dose of $100 \mathrm{mg} / \mathrm{kg} \mathrm{BM}$ daily and 10 females which were subjected to the dose of $30 \mathrm{mg} / \mathrm{kg} \mathrm{BM}$ daily). In this way we also intended to record the time of lead absorption and deposition in tissues and organs of experimental animals and its effects to AST, ALT, and ALP enzyme activities in the blood sera. The offspring of the $\mathrm{V}$ and $\mathrm{VI}$ group, i.e. females that were treated with lead within 50 and 60 days, as mentioned above, completed the lactation period and were able to grow. They were separated from their mothers, placed in separate cages and were not treated subsequently with lead - acetate because we only intended to observe the building-in and effects of lead they received from their mothers through the placenta and milk (Maldonado, 1995). They were kept until being sacrificed at the age of two months.

Blood was taken from all those sacrificed animals in order to separate the blood sera and determine the activities of AST, ALT and ALP enzymes.

The AST and ALT activities were determined by the IFCC spectrophotometric method (UV test). The ALP activity was determined colorimetrically by the IFCC method. To analyze the activities of the above enzymes, an automatic analyzer Hitachi 911 was used.

The following statistical methods were applied: mean value $(X)$, standard deviation (SD), standard error of the mean value (SE), Student's t-test, one-way variance analysis (ANOVA) and linear regression analysis.

\section{RESULTS}

Activities of the AST, ALT and ALP enzymes in the blood sera of rat females chronically poisoned daily with lead in doses of 100 and $30 \mathrm{mg} / \mathrm{kg} \mathrm{BM}$ showed a significant increase in in all experimental groups in relation to the control group. Differences which were found out showed statistical significance $(p<0.001)$ (Tables 1 and 2). 

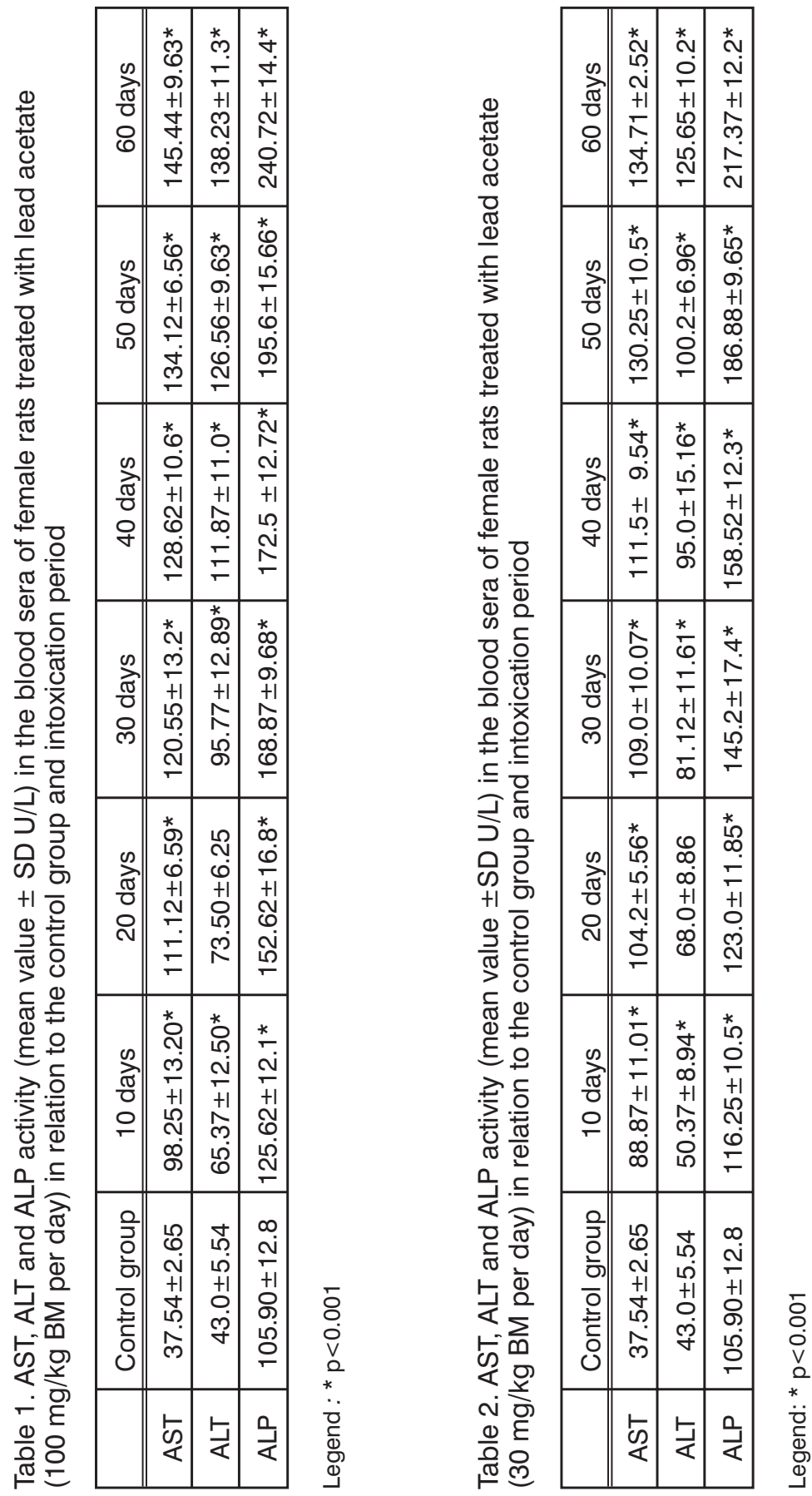
By correlating the time of intoxication and AST, ALT and ALP activities in the blood sera of chronically poisoned female rats a high level of correlation was established between these two parameters $(R=0.993$ and $R=0.981)$. By increasing the time of lead intoxication the activities of the above enzymes in the blood sera increased linearly. (Figures 1 and 2).

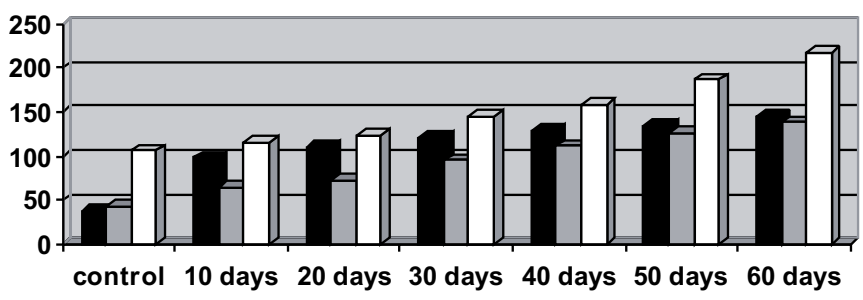

Figure 1. Correlation between the time of intoxication and the AST, ALT and ALP activity in the blood sera $(\mathrm{U} / \mathrm{L})$ of female rats treated with lead acetate $(100 \mathrm{mg} / \mathrm{kg}$ BM per day)

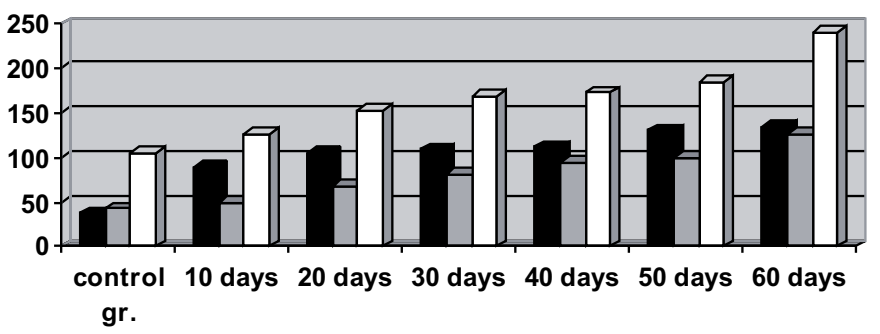

Figure 2. Correlation between the time of intoxication and the AST, ALT and ALP activity in the blood sera $(\mathrm{U} / \mathrm{L})$ of female rats treated with lead acetate $(30 \mathrm{mg} / \mathrm{kg}$ BM per day)

Comparing the activities of AST and ALT enzymes in the blood sera of female rats which received different doses of lead (100 and $30 \mathrm{mg} / \mathrm{kg} \mathrm{BM}$ daily) in equal time intervals, no statistically significant differences $(p>0.05)$ were established. However, statistical analysis of the results showed that the applied dose of lead strongly affects the ALP activity in the blood sera of female rats. Namely, a higher lead dosage (100 mg/kg BM daily) resulted in a higher increase of the ALP activity in the blood sera of female rats in relation to a lower dosage (30 $\mathrm{mg} / \mathrm{kg}$ BM daily) in equal time intervals (20,30, 40, 50 and 60 days). This fact did not apply only when the period of intoxication was 10 days.

One of the tasks in this study was to investigate the activities of enzymes in the blood serum of those young whose mothers were exposed to chronic lead 
poisoning during periods of pregnancy and lactation. The obtained results showed that the activities of the tested enzymes were significantly higher in the blood serum of the experimental young groups in relation to the control group, and the stated differences were statistically significant $(p<0.001)$ (Table 3$)$. Among the individual experimental groups of offspring (whose mothers received different lead doses) no significant differences were established in view of the activities of the above enzymes ( $p>0.05)$.

Table 3. AST, ALT and ALP activity in the blood sera of young rats (mean value \pm SD $\mathrm{U} / \mathrm{L}$ ) whose mothers were treated with lead acetate (100 and $30 \mathrm{mg} / \mathrm{kg}$ BM per day) during pregnancy and lactation in relation to the control group

\begin{tabular}{|c|c|c|c|}
\hline & Control group & $\begin{array}{c}100 \mathrm{mg} / \mathrm{kg} \mathrm{BM} \\
\text { per day }\end{array}$ & $\begin{array}{c}30 \mathrm{mg} / \mathrm{kg} \mathrm{BM} \\
\text { per day }\end{array}$ \\
\hline \hline AST & $30.0 \pm 3.12$ & $82.95 \pm 9.74^{\star}$ & $87.4 \pm 5.52^{\star}$ \\
\hline ALT & $32.65 \pm 3.23$ & $57.0 \pm 2.56^{*}$ & $63.0 \pm 6.32^{\star}$ \\
\hline ALP & $200.0 \pm 18.85$ & $356.46 \pm 29.68^{\star}$ & $364.35 \pm 43.36^{\star}$ \\
\hline
\end{tabular}

Legend: * $p<0.001$

\section{DISCUSSION}

In conditions of chronic lead poisoning of female rats and their offspring a significant increase in the activities of AST, ALT and ALP enzymes in the blood sera of experimental groups in relation to the control ones was determined. No dependence on the dose of lead was established for AST and ALT enzymes. However, for ALP, it was found out that the dose of lead significantly affected the level of ALP increase in the blood sera of female rats, while this was not the case with their offspring. Namely, a higher dose of lead resulted in a more significant increase of ALP activity in the blood sera of female rats. The dependence on the period of intoxication was established by extending the period of exposure to the influence of lead. The activities of the above enzymes in the blood sera linearly increased. The increase in the activity of the AST enzyme was more significant in relation to the ALT enzyme, i.e. the de Ritis coefficient (relation between AST/ALT activities) was higher than 1.

Increasing the activities of AST and ALT in the blood sera was most likely a consequence of the hepatotoxic effect of lead, i.e. the occurrence of toxic hepatitis. The above is also supported by the fact that the de Ritis coefficient was higher than 1. It is true that the liver, among its numerous other vital functions, has also a role in the process of accumulation and detoxication of foreign substances, and thus of toxic metals as well. The lead entering the body by ingestion is delivered to the liver through the portal blood circulation where the greatest part of it remains stored. Only a smaller part of this toxic metal "breaks the liver barrier" and enters the body circulation. The accumulated lead in the liver can act by directly damaging the hepatocytes, primarily by destroying the permeability of the 
cell membrane, which results in the increased release of cytosolic enzymes AST and ALT into the circulation. The exact mechanism of lead hepatotoxicity still remains unknown, although researchers suggest the tendency of lead to be bound to membranes, particularly to membranes of mitochondria. In addition to this, toxicity of lead, at the molecular level, is explained by the interaction between lead and calcium. Lead reacts with calcium on the basis of very similar ionic properties. These interactions are noticed at the level of $\mathrm{Ca}^{2+}$ entering the cell, at the level of $\mathrm{Ca}^{2+}$ - binding proteins and receptors and at the level of maintaining the stability of the cell membrane by means of calcium. Osteoblasts, neurons, capillary endothelial cells, as well as hepatocytes, accumulate the surplus of $\mathrm{Ca}^{2+}$ in mitochondria in the presence of lead. At the cell level, the interaction of lead and calcium is noticed at the level of the transport system of plasma membranes, such as the $\mathrm{Ca}^{2+}$ - channel and the $\mathrm{Ca}^{2+}$ - pump, lead disturbs the homeostasis of intracellular $\mathrm{Ca}^{2+}$ and reacts with numerous $\mathrm{Ca}^{2+}$ - dependent mechanisms, such as: calmodulin, protein kinase $\mathrm{C}$, etc. The most striking negative effect of lead is the disturbed homeostasis of calcium which results in increased entry of calcium into the cell. The $\mathrm{Ca}^{2+}$ ions are very reactive and lead to inhibition of mitochondrial function. When the function of mitochondria is disturbed, the energy release in the form of ATP is disturbed, this being the most important factor for maintaining the normal function of plasma membranes. The result of this is the destruction of the integrity and permeability of hepatocyte plasma membranes, which has as a consequence an increased release of cytosolic enzymes from the cell, as it is the case with AST and ALT. It is well known that the enzymes which are situated in the cytosol of the cell are most likely to release into the extracellular space even with minimal damages of cells, i.e. their membranes. While the process of damaging the cell and its membrane is continuing and developing, the quantity of enzymes which are released into the circulation is increasing. The results of this study proved this as with the extension of the intoxication period, the activities of AST and ALT in the blood sera of female rats were increased linearly. On the other hand, the factor which contributes to a quick release of enzymes from the liver cells is the high permeability of capillaries in the tissue. Another possible mechanism of lead hepatotoxicity is the indirect one - the interference within the metabolic ways and it is associated with the reduced concentration of cytochrome $p-450$. Lead disturbs liver function by inhibiting the enzymes which take part in protein synthesis (Pounds, 1991; Kahng, 1992; Goldstein, 1993; Goening, 1993; Grandjean, 1993; Simons, 1993; Fullmer, 1997; Schannef, 1997).

Concerning the lead dose, certain differences were noticed in view of the activities of AST and ALT in the blood sera of female rats. A higher dose of lead resulted in a somewhat higher activity of AST and ALT but these differences did not demonstrate a statistic significance. This can be explained with the fact that the enzymes AST and ALT do not belong to "fine" indicators of the liver damage at all levels, but only at the level of plasma membrane. It has been already emphasized that the dissolved enzymes from the cytosol of the cell release readily and quickly from the damaged cells even in case of minimal damages to the plasma membrane (e.g. edema without disturbing the integrity of the membrane). 
With young rats, whose mothers were intoxicated with lead at either higher or smaller doses during the periods of pregnancy and lactation, similar results were obtained. A significant increase in the AST and ALT activities in the blood sera of the experimental young rats groups in relation to the control group was established, while no significant differences were noticed in view of the lead dose. Therefore, it is likely that lead which has entered the young organism through the placenta and milk acts hepatotoxically.

The obtained results in this study are in accordance with the results of some former studies, but the available literature did not show data on the effects of lead to experimental young animals. A significant increase in the activities of AST and ALT in conditions of chronic lead poisoning in man and experimental animals has also been established. These studies explain the increase in the activities of these enzymes with the hepatotoxic action of lead. However, other studies have pointed out the significantly reduced activities of AST and ALT under the influence of lead. Authors explain this by a possible inhibition of the synthesis of the indicated enzymes under the influence of this toxic metal (Bodanovic,1991; Goering, 1993; Nisson,1993; Sollivaj, 1996). A possible explanation for such differing results is that the research studies were quite different in view of the experimental design and the applied doses of lead, length of exposition, the way how lead got into the organism and they also differed in that some of them were carried out on humans and others on different animal species.

Concerning ALP, this enzyme can be the indicator of both liver damage and bone damage which are associated to the increased activity of osteoblasts (Majkic-Singh, 1993). Apart from lead deposited in the liver, it can also deposit in bones. By increasing the time of intoxication it linearly increases its concentration in bone tissue. On culture of bone cells it was noticed that this toxic metal reduced the synthesis of proteins and collagen fibres of type I. Reduced synthesis of osteonectine, the protein which binds calcium was discovered. Interaction between lead and calcium was noticed at the level of osteoblasts. Namely, these cells accumulate the surplus of calcium in the mitochondria in the presence of lead and it has been found out that lead reacts with proteins and hormone signals, which normally regulate the status of intra- and extra-cellular calcium. Due to interaction between lead and calcium it is possible to significantly reduce the concentration of calcium in the bones in conditions of intoxication with this element, as some of the studies have already shown. This is most probably the matter of heteroionic replacement of calcium from the crystal hydroxyapatite by lead from the blood, because of their very similar electronic configurations. However, in spite of the presented negative effects which lead can have when found in bones, the majority of researchers still think that bones are not the primary place where its toxicity is demonstrated (Steenhout, 1982; Rosen, 1989; Angle, 1990, 1993; Long, 1990; Bronner, 1991; Jones, 1991; Nilsson, 1991; Puzas, 1991; Rabinovitz, 1991; Silbergeld, 1991; Legget, 1993; Miyuhara, 1994; Gerhardsson, 1996, Hac. and Krechinak, 1996, Schannef, 1997, Todorovic T. 1998).

With regard to the fact that pregnancy may affect the activity of ALP in the sense of increasing its activity, and due to the known fact that the placenta 
secretes a special isoenzyme, the observed increase in the ALP activity in pregnant female rats can be explained (Majkic-Singh, 1993). However, the control groups of pregnant females at the same stage of pregnancy which had not been treated with lead negated it.

In the light of the above indicated facts, the noticed increase of the ALP activity in the serum of experimental animals under the influence of lead in this study cannot be attributed to the increased release of this enzyme from either the bones or placenta, but from the liver and within the already mentioned hepatotoxicity. ALP is the enzyme known as a biochemical marker of intrahepatic cholestase, which happens in some forms of toxic hepatitis. As the pathologic process is developing over time, the level of intrahepatic cholestase is increasing and so the ALP activity is increasing in the blood serum, as the results of this study have shown.

The ALP activity in the blood sera of female rats depended basically on the applied dose of lead which was not the case when AST and ALT enzymes were concerned. Namely, a higher dose of lead resulted in significantly higher activity of ALP in the blood sera. This can be explained with the hypothesis that a higher dose of lead causes a higher level of intrahepatic cholestase.

The results obtained for the young rats were identical to results obtained for their mothers. Through the placenta and milk the lead gets into young rats and deposits in the liver and probably causes the occurence of toxic hepatitis followed by intrahepatic cholestase what results in the increased activity of ALP in the blood serum.

Some former studies produced results similar to those obtained in this study concerning the activity of ALP and lead poisoning but some other studies also produced different results - the reduced activity of ALP. The authors explain such results with interactions of lead and zinc and/or magnesium in the active site of the metalloenzyme ALP which resulted in a fall of the enzyme activity (Gviet, 1983; Matović et al, 1993; Vujanović et al, 1996; Todorovic and Vujanović, 2002). The available literature did not produce any data concerning the influence of lead on young rats in the periods of pregnancy and lactation.

Thus, when the influence of lead to the activity of ALP is concerned, various researches again have produced different results which may be the consequence of different experimental designs, as in the case of AST and ALT.

\section{CONCLUSIONS}

1. The activities of AST, ALT and ALP in the blood serum were significantly increased in conditions of chronic poisoning of female rats with lead. Such activities were closely dependent on the period of intoxication. With increasing the period of intoxication the activity of the above mentioned enzymes linearly increased, as well. The activities of AST and ALT were not dependent on the applied dose of lead while in the case of ALP, the increase in activity was basically dependent on the lead dose.

2. The activities of AST, ALT and ALP enzymes in the blood serum of young rats were significantly increased in conditions of chronic lead poisoning of their 
mothers during periods of pregnancy and lactation, but dependence on the dose of lead being received by their mothers was not established.

3. The increase in the activities of AST, ALT and ALP in the blood serum of experimental animals is the result of the hepatotoxic effect of lead followed by intrahepatic cholestase.

Address for correspondence:

Tatjana Todorović,

Faculty of Stomatology, Department of Biochemistry

Dr Subotića 8, 11000 Belgrade,

Serbia\& Montenegro,

e-mail: meche@yubc.net

\section{REFERENCES}

1. Ambrogi C, 1996, Delta-aminolevulic acid dehydratase and zinc protoporfirin in very low lead exposed pets, Vet-Hum-Toxicol, 38,5, 336-9.

2. Angle CR, 1993, Osteotoxicity of Cd and Pb in HOS TE 85 and ROS 17/2.8 cells, Biometals, 6,3, $179-84$.

3. Angle $C R, 1990$, Lead inhibits the basal and stimulated responses of a rat osteoblasts-like cell line, Toxicol-Appl-Pharmacol, 103, 281-7.

4. Atef $M, 1994$, Interaction between lead toxicity and some sulphonamides in rabbits, Effects on certain blood constituens and serum enzymes. DTSCH-Tieraiztl-Wachenschr, 101, 5, 187-90.

5. Aufderheide A, 1992, Selected aspects of the spatial distribution of lead in bone, Neurotoxicol, 13, 4, 809-19.

6. Aungust BJ and Fung $H L, 1985$, The effects of dietary $\mathrm{Ca}$ and $\mathrm{Pb}$ absorption, distribution and elimination kinetics in rats. J.Toxicol Environ Health, 16, 147-59.

7. Bogdanović M, 1991, Prilog poznavanju histopatoloskih efekata metala u uslovima hronicne profesionalne ekspozicije, Doktorska disertacija, Beograd.

8. Bronner F, 1991, Bone and calcium homeostasis. Workshop on lead metabolism and bone distribution, New York Press, 1-50.

9. Davis MJ, 1993, Current issues in human lead exposure and regulation of lead, Neurotoxicol, 14, 3, 501-6.

10. Dieter MR, 1993, Comparison of lead bioavailability in $\mathrm{F} 344$ rats fed lead acetate, lead oxide, lead sulfide or lead are concentrate from Skagway Alaska, JToxicol Environ Health, 39, 1, 79-93.

11. Freeman GB, 1994, Absolute biovailability of lead acetate and mining waste lead in rats, Toxicol, 9 , 2, 151-63.

12. Fullmer CS,1997, Lead - calcium interactionsm, Involment of vitamine D. Environ Res, 72, 1, 45-55.

13. Gerhardsson L, 1996, In vivo measurement of lead in bone in longterm exposed lead smettler workers, Arch Environ Health, 14, 3, $22-8$.

14. Goering PL, 1993, Lead - protein interactions as a basis for lead toxicity, Neurotoxicol, 14, 45-60.

15. Goldstein GW,1993, Evidence that lead acts as a calcium substitute in second messenger metabolism, Neurotoxicol, 14, 3, 97-103.

16. Grandjean $P, 1993$, International perspectives of lead exposure and lead toxicity, Neurotoxicol, 14, 3, 9-14.

17. Gviet $B, 1983$, Magnesium - a competitive inhibitor of lead, Magnesium deficiency, First European Congress on Mg, Lisbon.

18. Hac E, Krechinak J, 1996, Lead levels in bone and hair of rats treated with lead acetate, Biol Trace Elem Res, 52, 3, 293-301.

19. Ischiba M, Tomokuni K, 1988, Comparison of inhibition of erithrocyte pirimidin 5' nucelotidase and ALAD by lead, Toxicol Lett, 40, 2, 159-63. 
Acta Veterinaria (Beograd), Vol. 55. No. 5-6, 471-482, 2005.

Todorović Tatjana et al. The influence of chronic lead poisoning on

the activity of some serum enzymes in rats

20. Jones KW, 1991, Microdistribution of lead in bone, A new approach, Workshop on lead, New York, $33-66$.

21. Kahng M, 1993, Lead-binding proteins in human tissues, Toxicol, 12, 214 - 6.

22. Klein KF, 1992, Regulation of osteoblastic gene expresion by lead, Endocrinol, 132, 6, 2531-7.

23. Legget RW, 1993, An age-specific kinetic model of lead metabolism in humans, Environ Health Perspect, 101, 7, 598-616.

24. Long GF, 1990, Cellular lead toxixity and metabolism in primary and dental osteoblastic bone cells, Toxicol Appl Pharmacol, 102, 346-61.

25. Maldonado V, 1995, Lead intestinal absorption and mineralisation during lactation, Hum Exp Toxicol, 97, 1-3, 191-7

26. Matović V, Soldatović D, Vujanović D, 1993, Magnesium against lead, New approach to prophylaxis and therapy of chronic lead intoxication, Magn Res, 6, 2, 145-8.

27. Majkić-Singh N, 1994, Medicinska biohemija. Univerzitet u Beogradu, 156-89.

28. Majkić-Singh N, 1993, Klinicka enzimologija. Univerzitet u Beogradu, 236-324.

29. Massie HR, 1992, Lead accumulation in the bones of aging male mice, Gerontol, 38, 1-2, 13-7.

30. Miyuhara T, 1994, Effects of lead on osteoblasts-like cell formation in mouse bone marrow cell cultures, Calcif Tissue Int, 54, 2, 165-9.

31. Nehru B, Kaushal S, 1993, Alterations in the hepatic enzymes following experimental lead poisoning, Biol Trace Elem Res, 38, 1, 27-34.

32. Nilsson $U$, 1991, Kinetics of lead in bone and blood after the end of occupatioanl exposure, Pharmacol Toxicol, 68, 477-84.

33. O’ Flaherty EJ, 1995, Physiologically based models for bone - seeking elements, Lead apsorption and deposition in childhood, Toxicol Appl Pharmacol, 131, 2, 297-308.

34. O'Flaherty EJ, 1992, Modelling bone mineral metabolism with special reference to calcium and lead, Neurotoxicol, 13, 4, 789-97.

35. Patersson C, Settle D, 1993, New mechanisms in lead biodynamics at ultra-low levels Neurotoxicol, 14, 2-3, 291-9.

36. Pounds JG, 1991, Cellular and molecular toxicity of lead in bone, Environ Health Perspect, 91, 1732.

37. Pounds JG, 1985, Effect of lead intoxication on calcium homeostasis and calcium-mediated cell function, Neurotoxicol, 3, 295-332.

38. Puzas JE, 1991, Osteoblasts endochondrocytes are imprtant target cells for the toxic effects of lead, Workshop on lead, Metabolism and bone distribution, New York, 45 - 78

39. Rabinowitz MB, 1991, Toxicokinetics of bone lead, Environ Health Perspect, 91, 33-7.

40. Rabinowitz MB, 1991, Levels of lead in teeth, Bull Environ Contamin Toxicol, 47, 601-8.

41. Rosen JF, 1989, Quantitative interactions between $\mathrm{Pb}$ and Ca homeostasis in cultured osteoblastic bone cells, Toxicol Appl Phatmacol, 98, 530-4.

42. Schannef F, 1997, Lead induced rise in intracellular free $\mathrm{Ca}$ is mediated through activation of protein kinase C in osteoblastic bone cells, Biochim Biophys Acta, 1360, 3, 247-54.

43. Selander S, Cramer K, 1990, Interrelationships between lead in blood lead in urine and ALA in urine during lead work, Brit J Industr Med, 27, 28-39.

44. Simons TY, 1993, Lead - calcium interactions in cellular lead toxicity, Neurotoxicol, 14, 2-3, 77-86.

45. Silbergeld EK, 1993, Lead in bone Storage site, exposure source and target organ, Neurotoxicol, $14,2-3,225-36$

46. Silbergeld EK, 1991, Lead in bone Implications for toxicology during pregnancy and lactation, Environ Health Perspect, 91, 63-70.

47. Singh $B, 1994$, Impact of lead pollution on the status or other trace metals in blood and alterations in hepatic functions, Biol Trace Element Res, 40,1, 21-9.

48. Sollivaj $B, 1996$, Effect of exposure to lead on selected biochemical and haematological variables, Pharmacol Toxicol, 78, 18-22.

49. Steenhout A, 1982, Kinetics of lead storage in teeth and bones, An epidemilogical approach, Arch Environ Health, 37, 224-31. 
50. Todorović T, Vujanović D, 2002, The influence of magnesium on the activity of some enzymes (AST, ALT, ALP) and lead content in some tissues, Magn Res, 15,173-7.

51. Todorović $T, 1998$, Uticaj hroničnog trovanja olovom na sadržaj minerala u tkivima pacova, Doktorska disertacija, Stomatološki fakultet, Beograd,

52. Witmmers L, 1988, Lead in bone, Distribution in the human skeleton, Arch Environ Health, 43, 38191.

53. Vujanović D et al.,1996, Interakcije metala in vivo, Arch Pharmacol, 5-6, 285-306.

\section{UTICAJ HRONIČNOG TROVANJA OLOVOM NA AKTIVNOST NEKIH ENZIMA U KRVNOM SERUMU PACOVA}

TATJANA TODOROVIĆ, DOŽIĆ I, DRAGANA VUJANOVIĆ, PEJOVIĆ J I MARJANOVIĆ M

\section{SADRŽAJ}

U ovom radu su prikazani rezultati ispitivanja uticaja hroničnog trovanja olovom na aktivnost enzima aspartat i alanin aminotransferaze (AST i ALT), kao i alkalne fosfataze (ALP) u krvnom serumu pacova. Eksperiment je izveden na 130 ženki pacova i njihovih 80 mladunaca. Ženke su tretirane olovo-acetatom oralno putem pijaće vode u dve doze - 100 i $30 \mathrm{mg} / \mathrm{kg}$ TM dnevno u trajanju od 10, 20, 30, 40, 50 i 60 dana, dok su njihovi mladunci olovo primali samo preko placente i putem mleka. Nakon žrtvovanja, od životinja je uzimana krv i u krvnom serumu je spektrofotometrijski, na automatskom analizatoru Hitachi 911, određivana aktivnost enzima AST, ALT i ALP.

Dobijeni rezultati su ukazali da hronično trovanje olovom ima za posledicu značajno povećanje aktivnosti enzima AST, ALT i ALP u krvnom serumu ženki pacova, pri čemu se aktivnost navedenih enzima linearno povećavala sa povećanjem vremena intoksikacije. Nisu zapažene značajne razlike u aktivnosti enzima AST i ALT u odnosu na primenjenu dozu olova, dok je u slučaju ALP ustanovljeno da veća doza olova ima za posledicu značajnije povećanje aktivnosti ovog enzima u krvnom serumu. U mladunaca ženki koje su tokom trudnoće i laktacije primale olovo, takođe je ustanovljeno značajno povećanje aktivnosti navedenih enzima u krvnom serumu u odnosu na kontrolnu grupu. Nisu ustanovljene značajne razlike u aktivnosti AST, ALT i ALP u serumu mladunaca u pogledu doze olova koje su njihove majke primale.

Povećanje aktivnosti enzima AST, ALT i ALP u krvnom serumu ženki i mladunaca je najverovatnije posledica hepatotoksičnog dejstva olova udruženog sa intrahepatičkom holestazom. 